\title{
Absorption of m-xylene vapours through the respiratory tract and excretion of m-methylhippuric acid in urine
}

\author{
W. SEŃCZUK AND J. ORŁOWSKI \\ From the Department of Toxicological Chemistry, Institute of Analytical Chemistry, Academy of Medicine, \\ Poznań, Grunwaldzka 6, Poland
}

ABSTRACT Absorption of m-xylene and excretion of m-methylhippuric acid were investigated under controlled conditions in ten volunteers aged 17-33 years. They were exposed to m-xylene vapours at concentrations of 100,300 , and $600 \mathrm{mg} / \mathrm{m}^{3}$. It was found that $\mathrm{m}$-xylene vapour retained in the lungs tended to decrease at the end of the exposure. An exposure test was devised, based upon the results obtained during our investigations. The amount of xylene absorbed in the course of eight hours' work can be calculated with an accuracy of about $\pm 8 \%$.

In order to define the degree of exposure to aromatic compounds in industrial conditions, tests based on the excretion of their metabolites have been used for several years. Such tests have been devised for compounds such as aniline (Dutkiewicz, 1962), styrene (Bardoděj, 1964), toluene (Piotrowski, 1967), phenol (Piotrowski, 1971a), and benzene (Dutkiewicz, 1971). Ogata et al. $(1970,1971)$ tried to calculate the absorption index of xylene, attempting to relate the exposure to $\mathrm{m}$ - and $\mathrm{p}$-xylene to the excretion of methylhippuric acid.

As a result of these investigations it could be deduced whether the exposure took place in conditions exceeding the highest permissible concentration. We initially proposed measurements of the total quantity of the excreted metabolite, i.e., the determination of the metabolite in the urine collected, during exposure, and eighteen hours after it was ended, as the best procedure. As it is very difficult, however, to collect urine over such a long time from occupationally exposed subjects, another solution has been found. It consists of measuring the rate of urinary excretion of the metabolite or of determining its concentration, after adjustment for the specific gravity of urine (1.024), collected after the first three hours, or between four and eight hours of exposure, or during the total eight hours' exposure.

Received for publication 20 February 1976 Accepted for publication 2 August 1977
Unlike Ogata et al. (1970), we therefore attempted to find tests based on measurement of the rate of excretion of m-methylhippuric acid in urine in order to determine the quantity of $\mathrm{m}$-xylene absorbed during occupational exposure; this would then allow the risk incurred in exposure to xylene to be assessed.

\section{Methods}

Thirty experiments were carried out on 10 healthy people (five women and five men), aged 17-33 years. Before the investigations they underwent thorough medical examinations, they were not exposed to the action of m-xylene, nor did they take any medicine. Subjects were exposed to $\mathrm{m}$-xylene in an inhalation chamber constructed in such a way that they could be examined during inhalation (Seńczuk and Orłowski, 1974).

The chamber (Fig. 1), $0.125 \mathrm{~m}^{3}$ in size, was constructed of polymethacrylene plates. There was a hole in the base closed by a nylon foil sleeve (1), into which the exposed subjects placed their heads.

A mixture of $\mathrm{m}$-xylene vapour and air was introduced into the chamber through an inlet (2), while the excess mixture was removed through a lower outlet (3). In the front wall of the chamber were holes (4) for tubes to sample air inhaled or exhaled by the exposed subject. In the upper part of the chamber was a fan (5) to ensure even distribution of $\mathrm{m}$-xylene vapour and air throughout the chamber.

In our experiments, exposure lasted eight hours 


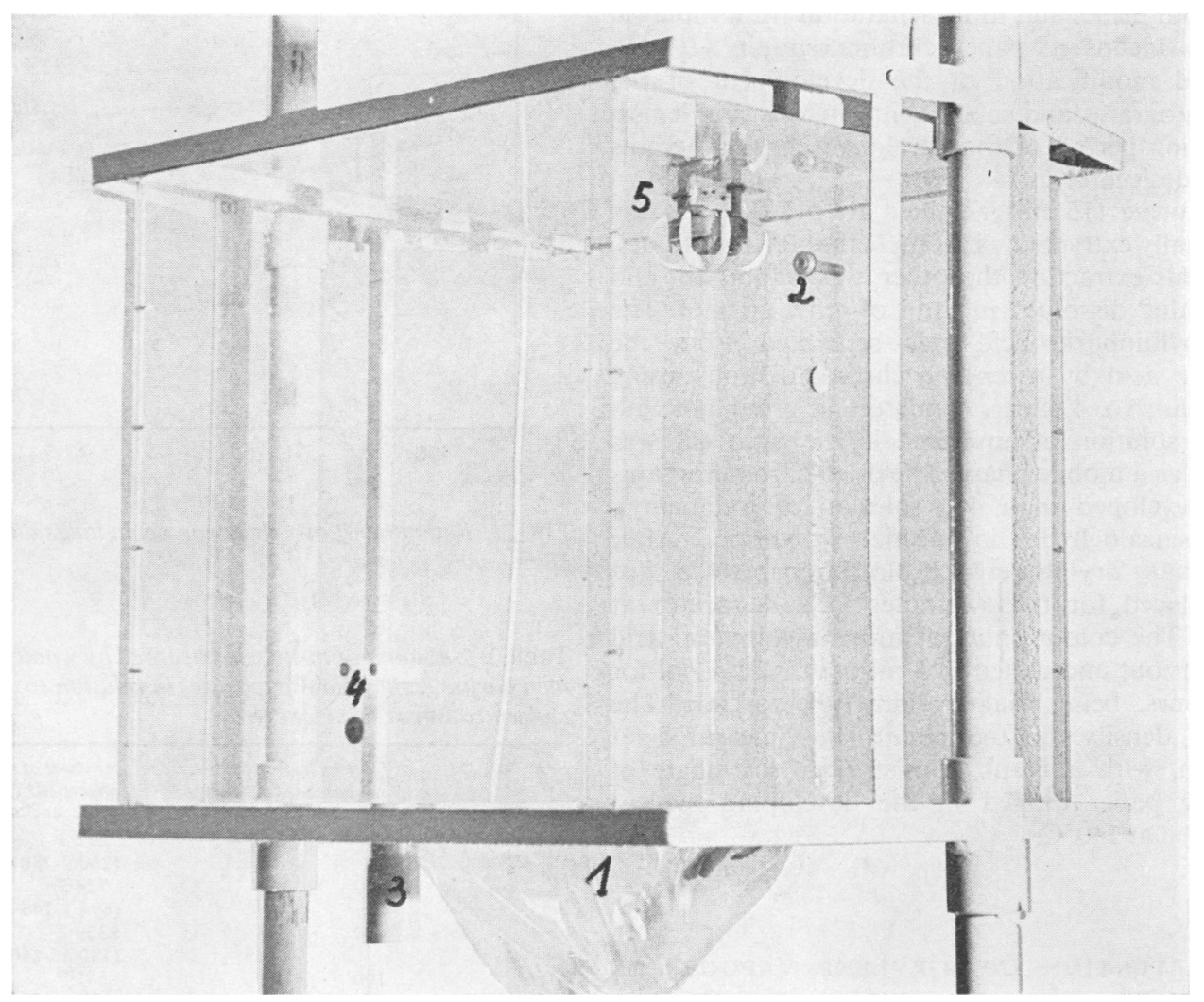

Fig. 1 Exposure chamber.

with two 30 -minute breaks after $2 \frac{1}{2}$ and $5 \frac{1}{2}$ hours' exposure. During the breaks the subjects took their meals and drank cups of tea. Each subject was exposed, at intervals of ten days, to three different concentrations of $\mathrm{m}$-xylene $\left(100,300\right.$ and $\left.600 \mathrm{mg} / \mathrm{m}^{3}\right)$ in turn. The necessary concentration of $\mathrm{m}$-xylene vapour was obtained by evaporating it from the container, where a constant volume of the fluid was kept throughout the whole experimental period.

The concentration of $m$-xylene in the air both inhaled and exhaled was determined in all exposed subjects by gas chromatography. The samples of exhaled air, each of $10 \mathrm{ml}$, were obtained by a tube placed in the front of the inhalation chamber, through which the exposed subjects exhaled the air during measurement. The samples were measured in the initial phase of exposure and at the end. Urine was collected during and after exposure at $3,6,8,12,24$ and 32 hours from the beginning of the exposure period.

M-xylene in air was determined by gas chromatography (Giede GCHF, 18.3). The column, length $3 \mathrm{~m}$, and diameter $4 \mathrm{~mm}$, was filled with chromosorb
W (30-60 mesh), covered with $5 \%$ bentonite $34,5 \%$ squalane and $2 \%$ dinonyl phthalate. The chromatograph had a flame ionisation detector. The determination was performed at $75^{\circ} \mathrm{C}$ : the flow rate of the carrier gas was $50 \mathrm{ml} / \mathrm{min}$ and the temperature of the injection chamber was $140^{\circ} \mathrm{C}$. The precision of the method was $\pm 4.5 \%$.

The 10-ml air samples were injected into the chromatograph column by a glass syringe. In order to check the method, a static mixture of m-xylene vapour and air was prepared in a glass bottle containing 33 litres. Taking various quantities of air from the glass bottle a calibration diagram was prepared. Gas chromatography was used in parallel with measurements by u.v. spectrophotometry (Seńczuk et al., 1971). In the latter method the air was drawn through a scrubber containing $6 \mathrm{ml}$ of $95 \%$ ethyl alcohol. One litre of air was passed at a rate of $10 \mathrm{l} / \mathrm{h}$. The precision of this method was $\pm 4.7 \%$.

M-methylhippuric acid in urine was determined by the colorimetric method of Ogata et al. (1969) as modified by Orłowski (1974). The modification of the method was in isolating the m-methylhippuric 
acid from urine, and in its separation from hippuric acid by means of paper chromatography. It also involved modification of the development of the chromatograms and subsequent intensity and length of heating period of the developed chromatograms in the desiccator.

The urine $(15 \mathrm{ml})$ acidified to $\mathrm{pH} 2 \cdot 0-2 \cdot 5$, was continually extracted with ethyl ether for four hours. After this extraction the ether was vaporised and the residue dissolved in $3 \mathrm{ml}$ of ethyl alcohol. The m-methylhippuric acid was separated from the hippuric acid by ascending chromatography, using Whatman No. 4 paper. A mixture of $n$-butanol with a $25 \%$ solution of ammonia in the ratio 4:1 was applied as a mobile phase. The dried chromatograms were developed in a $4 \%$ solution of p-dimethylaminobenzaldehyde in acetic anhydride. After preliminary drying between blotting paper the slips were placed for three minutes in a desiccator at $140^{\circ} \mathrm{C}$. The colour spots of m-methylhippuric acid were cut out and eluted in $5 \mathrm{ml}$ of ethyl alcohol for two hours, being shaken from time to time. The optical density of the eluate was measured at $470 \mathrm{~nm}$, with a blank consisting of an eluate of blotting paper dipped in the developing reagent and dried at $140^{\circ} \mathrm{C}$.

Results

THE RETENTION OF M-XYLENE VAPOURS IN THE LUNGS

During exposure lung ventilation fluctuated; on average it was $0.458 \mathrm{~m}^{3} / \mathrm{h} \pm 0.036$ for women and $0.575 \mathrm{~m}^{3} / \mathrm{h} \pm 0.041$ for men. Mean retention values for different concentrations used during exposure are given in Fig. 2. The retention decreased during exposure, and this was clearly visible in higher concentrations of $\mathrm{m}$-xylene in air. A decrease of retention was observed from $83 \%$ to $67 \%$ (mean $75 \%$ ), when the concentrations of $\mathrm{m}$-xylene were $300 \mathrm{mg} / \mathrm{m}^{3}$, and at $600 \mathrm{mg} / \mathrm{m}^{3}$ the initial retention was $78 \%$, while at the end of the exposure it was $65 \%$ (mean $71 \%$ ). The fluctuations in retention when the concentration was $100 \mathrm{mg} / \mathrm{m}^{3}$ of air were less perceptible, because the initial retention was $87 \%$ and the final retention was $84 \%$ (mean $85 \%$ ).

Table 1 shows the quantities of absorbed m-xylene, taking into account the retention, lung ventilation and exposure time with varying concentrations of $\mathrm{m}$-xylene vapour. The results showed that there was a directly proportional dependence between the absorbed dose of $m$-xylene and the quantity of the excreted metabolite m-methylhippuric acid. The metabolic capacity in relation to the quantity of absorbed $\mathrm{m}$-xylene in $\mathrm{mol} \%$ is $90.1 \%$ on average. Excretion of m-methylhippuric acid with urine at

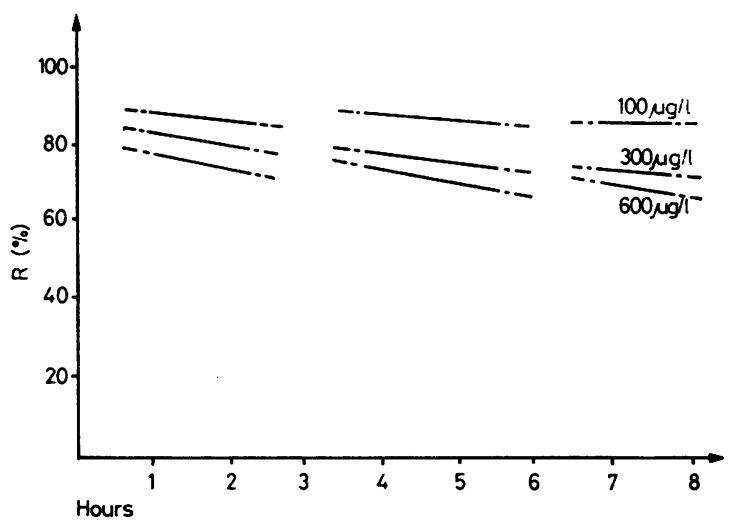

Fig. 2 Retention of $m$-xylene vapour in lungs during eight hours' exposure.

Table 1 Amount of m-xylene absorbed by women and men during eight hours' exposure, in relation to the concentration of $m$-xylene in air

\begin{tabular}{|c|c|c|}
\hline Sex & $\begin{array}{l}\text { Concentration of m-xylene } \\
\text { in chamber }\left(\mathrm{mg} / \mathrm{m}^{3}\right)\end{array}$ & $\begin{array}{l}\text { Amount of m-xylene } \\
\text { absorbed }{ }^{*}(\mathrm{mg})\end{array}$ \\
\hline \multirow[t]{3}{*}{ Women } & 100 & $\begin{array}{l}272 \cdot 3 \\
(260 \cdot 9-280 \cdot 6)\end{array}$ \\
\hline & 300 & $\begin{array}{l}724 \cdot 3 \\
(694 \cdot 1-746 \cdot 3)\end{array}$ \\
\hline & 600 & $\begin{array}{l}1359 \cdot 2 \\
(1306 \cdot 5-1404 \cdot 9)\end{array}$ \\
\hline \multirow[t]{3}{*}{ Men } & 100 & $\begin{array}{l}341 \cdot 9 \\
(328 \cdot 4-359 \cdot 9)\end{array}$ \\
\hline & 300 & $\begin{array}{l}909 \cdot 2 \\
(873 \cdot 5-957 \cdot 1)\end{array}$ \\
\hline & 600 & $\begin{array}{l}1711 \cdot 6 \\
(1644 \cdot 4-1801 \cdot 7)\end{array}$ \\
\hline
\end{tabular}

* range of values ( 5 subjects) in parentheses.

different time intervals according to the quantity of $\mathrm{m}$-xylene absorbed is shown in Table 2.

KINETICS OF EXCRETION OF M-METHYLHIPPURIC ACID

Figure 3 shows a typical excretion curve of $\mathrm{m}$ methylhippuric acid in urine during and after exposure. During exposure the rate of excretion increased markedly, and the maximum value was found in the urine fraction collected in the last two hours of exposure. After exposure the rate of excretion decreased, tending in the course of 32 hours' observation to values near zero.

In order to compare the processes of excretion of m-methylhippuric acid a conversion system eliminating the differences in metabolite concentrations in urine, which was collected at different time intervals, according to the amount of inhaled m-xylene, was applied in all experiments. The results of these, 
Table 2 Excretion of m-methylhippuric acid by women and men during various time intervals in relation to the concentration of $m$-xylene in inhaled air

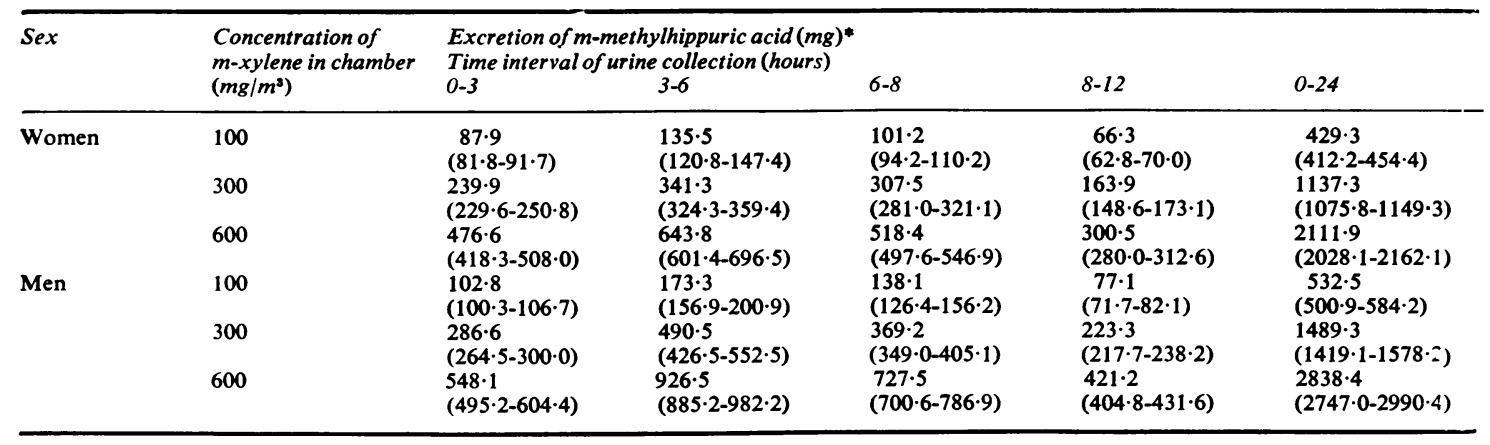

* Mean results of five estimations : range in parentheses.

irrespective of the concentration of m-xylene vapours in air, are therefore presented as a ratio of the rate of excretion of m-methylhippuric acid to the rate of absorption of $\mathrm{m}$-xylene in $\mathrm{mol} / \mathrm{h}$. Analysis of the results for different concentrations indicated that there were no significant differences. The average process of excretion, based on all experimental measurements, is shown in Figure 4. This may be described by the equation given by Piotrowski (1971b). Assuming that the rate of excretion of m-methylhippuric acid in the range of doses studied is kinetically of the first order:

$$
\frac{\mathrm{u}}{\mathrm{q}}=\mathrm{w}\left(1-\mathrm{e}^{-\mathrm{kTm}}\right) \mathrm{e}^{-\mathrm{k}(\mathrm{T}-\mathrm{Tm})}
$$

where:

$$
\begin{array}{ll}
\mathbf{u} & =\text { rate of excretion in } \mathrm{mol} / \mathrm{h} \\
\mathbf{q} & =\text { rate of absorption in mol/h } \\
\mathbf{w} & =\text { conversion factor } \\
\mathbf{k} & =\text { constant characterising the rate of } \\
& \text { excretion } \\
\mathrm{Tm} & =\text { time of excretion during exposure }
\end{array}
$$$$
\mathbf{T}-\mathrm{Tm}=\text { time of excretion after exposure }
$$

The function is shown in Fig. 4 by the broken line, assuming that the constant $\mathrm{k}=0.5$ hours $^{-1}$.

From the kinetic point of view the rate constant $k$ may characterise either the rate of excretion of the metabolite in urine, or the rate of metabolism of $\mathrm{m}$-xylene in the body. In order to investigate these possibilities an additional experiment was carried out to study the excretion of the m-methylhippuric acid itself, after ingestion of $1.5 \mathrm{~g}$ of the acid. Urine samples were collected after 1, 2, 4, 6, 10,14, 19 and 24 hours. The results, using a semi-logarithmic plot (Fig. 5), show that the excretion of m-methyl-

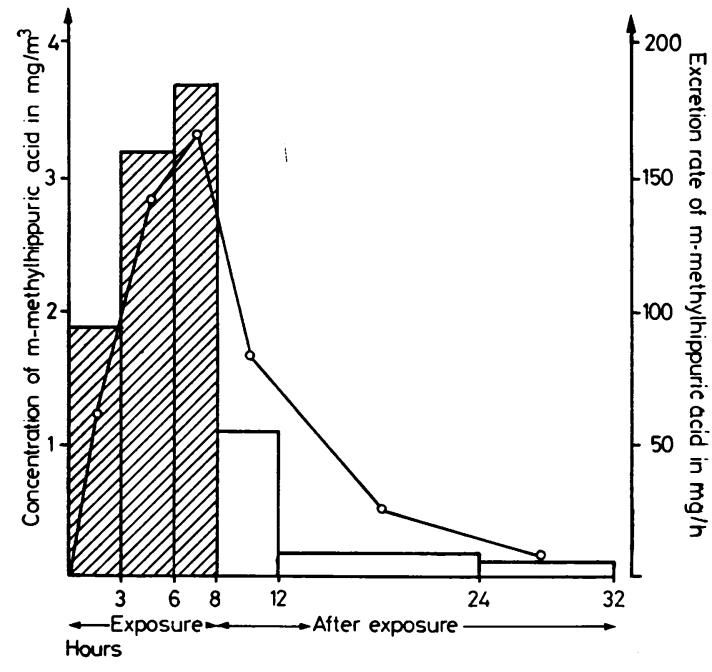

Fig. 3 Concentration and rate of excretion of m-methylhippuric acid in the urine of men exposed by the respiratory route to $\mathrm{m}$-xylene vapour up to $300 \mathrm{mg} / \mathrm{m}^{3}$.

hippuric acid in urine is rectilinear (single-phase) with a constant $k=0.53$, i.e., it approximates to the theoretical constant $\mathbf{k}=0 \cdot 5$. The consistency of the values indicates that the constant $k=0.5 h^{-1}$ arises from the rate of excretion of m-methylhippuric acid in urine, and not from the rate of metabolism of m-xylene.

It is concluded that the metabolism of one of the methyl groups of $\mathrm{m}$-xylene, followed by conjugation with glycine, is very rapid.

EXPOSURE TEST

The excretion of the metabolite in the urine may be 


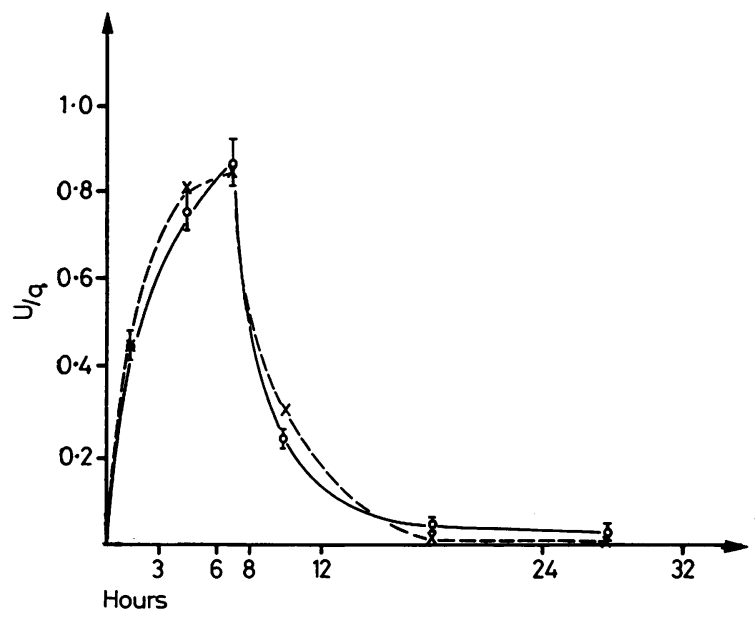

Fig. 4 Rate of excretion of m-methylhippuric acid as a function of time. The rate is expressed as a fraction of the rate of absorption. The broken line represents the theoretical curve for $k=0.5$ hours $^{-1}$.

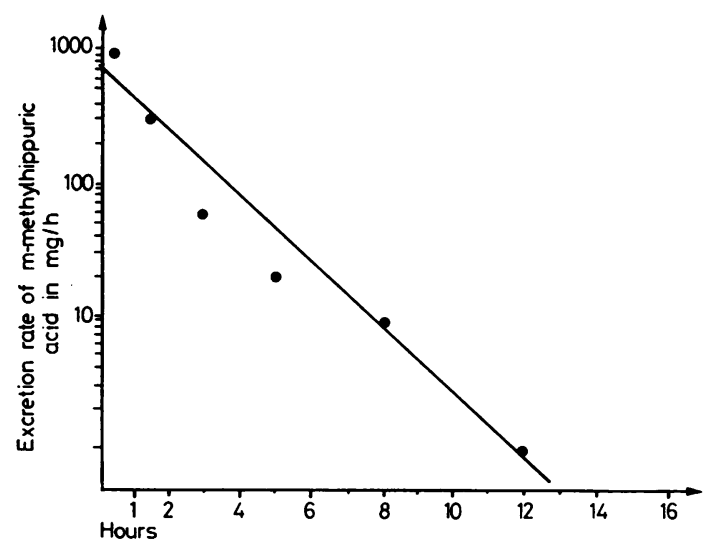

Fig. 5 The excretion of m-methylhippuric acid after oral administration.

expressed quantitatively in different units, such as excretion in 24 hours $(\mathrm{mg} / 24 \mathrm{~h})$, concentration in urine, or rate of excretion. From a toxicological point of view any unit is acceptable if it satisfies two conditions: that there is a good correlation between the calculated and given doses, and that the test is suitable for routine use. In Table 3 three different variants of the exposure test are given, based on measurements of the excretion rate of $\mathrm{m}$-methylhippuric acid. The proposed test is of practical value in the range of concentrations examined, as the correlation coefficient (0.99)
Table 3 Variants of exposure tests

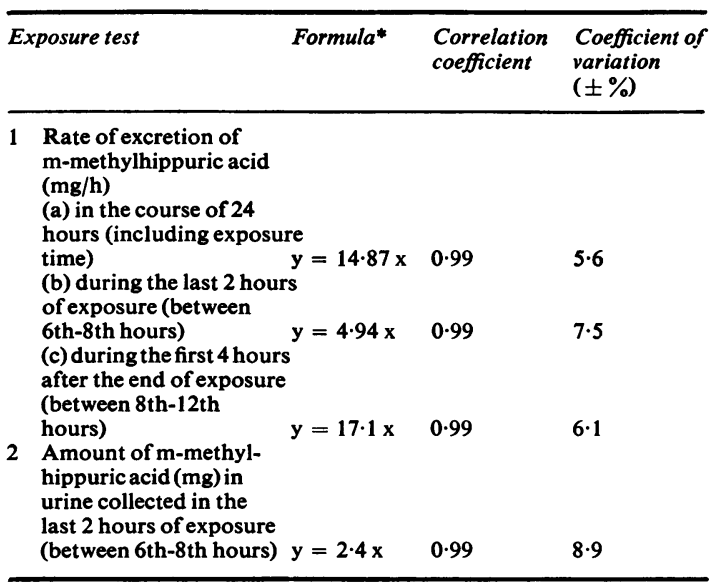

* $y=$ dose of absorbed $m$-xylene (mg); $x$ = excretion of m-methylhippuric acid in units shown.

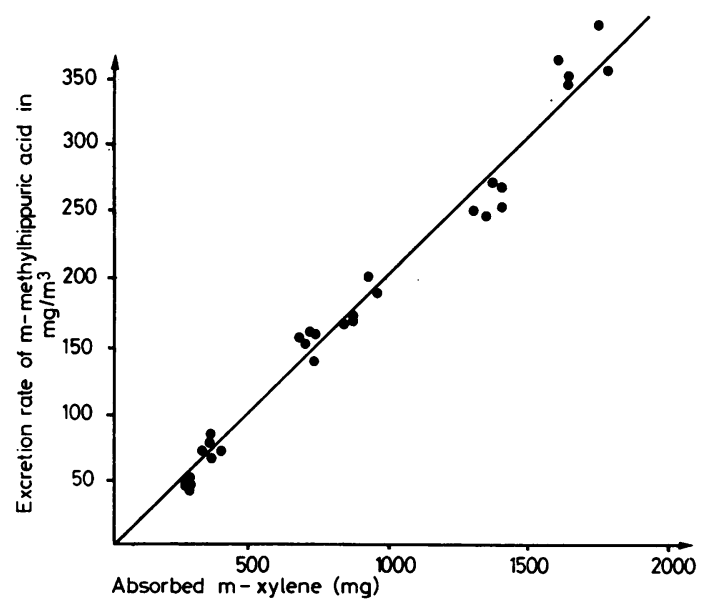

Fig. 6 The rate of excretion of m-methylhippuric acid in urine collected during the last two hours of exposure as a fraction of the absorbed m-xylene dose.

between the excretion rate of $m$-methylhippuric acid and the absorbed dose of $\mathrm{m}$-xylene is highly significant. In Figure 6 the correlation between the rate of excretion of the metabolite in urine during the last two hours of exposure, and the absorbed $\mathrm{m}$-xylene dose, is illustrated graphically.

\section{Discussion}

The results show that the recorded course of excretion of m-methylhippuric acid is similar to that 
described by Ogata et al. $(1970,1971)$. A similar process of excretion was also found in studies on benzene and toluene carried out by Dutkiewicz (1971) and Piotrowski (1967). These authors stated that the greatest excretion of the metabolites of these compounds took place between the sixth and eighth hour of exposure. In their studies, as well as in this paper, decreasing retention of solvent vapour was found during exposure, and this is shown in Figure 2.

The theoretical excretion process (broken line) depicted in Fig. 4, with the excretion coefficient $\mathrm{k}=0.5 \mathrm{~h}^{-1}$, demonstrates that $\mathrm{m}$-xylene does not accumulate in the body during one day's exposure, or does so only to a very small degree.

As a result of additional studies, when m-methylhippuric acid was orally administered, the constant $k=0.53 \mathrm{~h}^{-1}$ was calculated. The latter is characteristic of the excretion rate of the metabolite in urine.

In this paper it has been stated that there is a relationship between the absorbed dose of $m$-xylene and the rate of excretion of m-methylhippuric acid between the sixth to eighth hour of exposure; this is shown in Fig. 6. The correlation coefficient (0.99) is high. There is a similar dependence during the other time intervals.

The results of examinations of different forms of exposure tests are shown in Table 3. The amount of $\mathrm{m}$-xylene absorbed can be calculated on the basis of measurements of the rate of excretion of m-methylhippuric acid during eight hours' work. Of all the proposed variants of the test the most useful from the practical point of view seem to be tests $1 \mathrm{~b}$ and $1 \mathrm{c}$, as well as 2 , in which the time of collection of urine is very convenient, as opposed to test $1 \mathrm{a}$, in which the collection of urine over the course of 24 hours is very difficult.

The results of these studies allow us to determine not only the probable concentration of m-xylene during exposure (as in the studies of Ogata $e t$ al, 1971) but also the amount absorbed.

Other variants than those shown in Table 3 are, of course, possible. The high correlation coefficient obtained in the range examined in this study is worth noting, and so is the great precision of measurement.

\section{References}

Bardoděj, Z. (1964). Metabolismus styreńu. Ceskoslovenskd Hygiena, 9, 223-239.

Dutkiewicz, T. (1962). In Wchlanianie $i$ Metabolizm Aniliny u Ludzi, pp. 47-52. Lódzkie Towarzystwo Naukowe: Lódź.

Dutkiewicz, T. (1971). Wchłanianie par benzenu w drogach oddechowych u ludzi. Bromatologia $i$ Chemia Toksykologiczna, 4, 253-259.

Ogata, M., Tomokuni, K., and Takatsuka, Y. (1969). Quantitative determination in urine of hippuric acid and $\mathrm{m}$ - or p-methylhippuric acid, metabolites of toluene and $\mathrm{m}$ - or p-xylene. British Journal of Industrial Medicine, 26, 330-334.

Ogata, M., Tomokuni, K., and Takatsuka, Y. (1970). Urinary excretion of hippuric acid and m- or p-methylhippuric acid in the urine of persons exposed to vapours of toluene and m- or p-xylene as a test of exposure. British Journal of Industrial Medicine, 27, 43-50.

Ogata, M., Takatsuka, Y., and Tomokuni, K. (1971). Excretion of hippuric acid and $\mathrm{m}$ - or p-methylhippuric acid in the urine of persons exposed to vapours of toluene and $\mathrm{m}$ - or p-xylene in an exposure chamber and in workshops, with specific reference to repeated exposures. British Journal of Industrial Medicine, 28, 382-385.

Orłowski, J. (1974). Ocena narażenia na toksyczne działanie ksylenu na podstawie pomiarów metabolitów w moczu. Cz. III. Kolorymetryczna metoda oznaczania kwasu m-metylohipurowego w moczu. Bromatologia $i$ Chemia Toksykologiczna, 7, 87-91.

Piotrowski, J. (1967). Ilościowa ocena wchłaniania toluenu u ludzi. Medycyna Pracy, 18, 213-223.

Piotrowski, J. (1971a). Evaluation of exposure to phenol: absorption of phenol vapour in the lungs and through the skin and excretion of phenol in urine. British Journal of Industrial Medicine, 28, 172-178.

Piotrowski, J. (1971b). The Application of Metabolic and Excretion Kinetics to Problems of Industrial Toxicology, 73-80. U.S. Government Printing Office: Washington, 1971.

Seńczuk, W., Litewka, B., Orłowski, J., and Pogorzelska, H. (1971). Ocena narażenia na toksyczne działanie ksylenu na podstawie pomiarów metabolitów w moczu. $\mathbf{C z}$. I. Wydzielanie kwasu m-metylohipurowego. Annales Pharmaceutici, 9, 3-9.

Seńczuk, W., and Orłowski, J. (1974). Ocena narażenia na toksyczne działanie ksylenu na podstawie pomiarów metabolitów w moczu. Cz. IV. Opis i charakterystyka inhalacyjnej komory doświadczalnej. Bromatologia $i$ Chemia Toksykologiczna, 7, 83-85. 